\title{
PENGARUH KINERJA KEUANGAN TERHADAP HARGA SAHAM PADA PERUSAHAAN PROPERTI DAN REAL ESTATE YANG TERDAFTAR DI BURSA EFEK INDONESIA
}

\author{
Made Galih Wisnu Wardana \\ Wisnugalih17@gmail.com \\ Universitas Ahmad Dahlan \\ Muhammad Ali Fikri \\ muhammad.fikri@mgm.uad.ac.id \\ Universitas Ahmad Dahlan
}

\begin{abstract}
ABSTRAK
This research aims to determine the effect of liquidity ratio (CR), solvency ratio (DER), profitability ratio (ROA), and activity ratio (TATO) on the Stock Price. The object that is used in this research are property and real estate sub sector companies listed in Indonesia Stock Exchange year 2015-2017. The population in this research is a whole of property and real estate sub sector companies listed in Indonesia Stock Exchange year 2015-2017 were 48 companies. The sampling technique is used purposive sampling with several criteria, namely property and real estate sub sector companies listed in Indonesia Stock Exchange year 20152017, companies that submit financial reports during the research period, and companies that have positive net income report. The number of samples that fit the criteria were 34 companies. Data were analyzed by using data regression analysis with Eviews 6 software. The results of this research showed that current ratio, debt to equity ratio and total asset turn over are partially have positive and not have significant effect on the stock price, while return on assets have negative and not have significant effect on the stock price. Simultaneously that the current ratio, debt to equity ratio, return on assets and total asset turnover not have significant effect on the stock price. R-square value of 0.019 indicates that the ability of the current ratio, debt to equity ratio, return on assets, and total asset turnover while explaining the Stock Price is $1.9 \%$, and the $98.1 \%$ is explained by other variables which not contained in this research.
\end{abstract}

Keywords: Liquidity Ratio (CR), Solvency Ratio (DER), Profitability Ratio (ROA), Activity Ratio (TATO), Stock Price.

\section{PENDAHULUAN}

Pengertian pasar modal menurut Undang-Undang Pasar Modal No. 8 Tahun 1995 yaitu sebagai suatu kegiatan yang bersangkutan dengan penawaran umum dan perdagangan efek, perusahaan publik yang berkaitan dengan efek yang diterbitkannya, serta lembaga dan profesi yang berkaitan dengan efek. Fahmi (2012) menjelaskan bahwa pasar modal adalah tempat berbagai pihak, khususnya perusahaan menjual saham (stock) dan obligasi (bond), dengan tujuan dari hasil penjualan tersebut nantinya akan digunakan sebagai tambahan dana untuk memperkuat modal perusahan. Martalena (2011) menambahkan bahwa pasar modal merupakan sarana pendanaan bagi perusahaan maupun institusi lain (misalnya pemerintah), dan sebagai sarana bagi kegiatan berinvestasi. Dari beberapa pengertian di atas, dapat disimpulkan bahwa pasar modal merupakan tempat 
bagi perusahaan menawarkan efek kepada para investor. Tujuan dari bergabungnya perusahaan ke dalam pasar modal adalah untuk menawarkan saham perusahaannya. Lebih lanjut, perusahaan ingin menarik minat para investor untuk menanamkan modal berupa investasi yang akan digunakan untuk kemajuan perusahaan. Investor akan menanamkan investasi untuk memperoleh kedihupan yang lebih layak di masa yang akan datang dari hasil pengembalian (return) atas investasi pada perusahaan (Tandelilin, 2010).

Nainggolan (2008) menjelaskan bahwa faktor fundamental perusahaan memegang peran penting dalam proses pengambilan keputusan. Informasi fundamental adalah informasi yang berhubungan dengan kondisi perusahaan yang umumnya ditunjukkan dalam laporan keuangan yang menjadi salah satu ukuran kinerja perusahaan. Hal tersebut sangat penting bagi para investor sebelum menanamkan investasi terhadap perusahaan agar tidak mengalami kerugian dikemudian hari. Zuliarni (2012) menambahkan bahwa kepercayaan investor atau calon investor sangat bermanfaat bagi emiten, karena semakin banyak orang yang percaya terhadap emiten, maka keinginan untuk berinvestasi pada emiten semakin kuat. Hal ini menjelaskan bahwa semakin banyak permintaan terhadap saham suatu emiten, maka dapat meningkatkan harga saham perusaahaan.

Sutrisno (2012) menjelaskan saham adalah surat bukti kepemilikan perusahaan atau pernyataan pada perusahaan yang berbentuk perseroan terbatas. Martalena (2011) menambahkan bahwa saham dapat didefinisikan sebagai tanda penyertaan modal seseorang atas pihak (badan usaha) dalam suatu perusahaan atau perseroan terbatas dengan menyertakan modal, maka pihak tersebut memiliki klaim atas pendapatan perusahaan. Dari pengertian di atas, dapat disimpulkan bahwa saham merupakan surat berharga yang diperjual belikan dalam pasar modal, dimana pemegang saham memiliki hak atas perundapatan dari perusahaan.

Darmadji (2012) menjelaskan harga saham adalah harga yang terjadi di bursa pada waktu tertentu. Harga saham bisa berubah naik atau turun dalam hitungan waktu yang begitu cepat. Harga saham dapat berubah dalam hitungan menit bahkan dalam hitungan detik. Hal tersebut dimungkinkan karena tergantung dengan permintaan dan penawaran antara pembeli saham dengan penjual saham. Martalena (2011) menambahkan bahwa pembentukan harga saham terjadi karena adanya permintaan dan penawaran atas saham tersebut. Dengan kata lain, harga saham terbentuk oleh supply dan demand harga saham tersebut. Dari pengertian di atas dapat disimpulkan bahwa harga saham adalah harga dari suatu saham yang ditentukan pada saat pasar saham berlangsung yang dipengaruhi oleh permintaan dan penawaran.

Salah satu faktor yang dapat mempengaruhi kenaikan harga saham adalah kinerja keuangan perusahaan yang dapat dianalisis melalui laporan keuangan perusahaan (Fahmi, 2012). Kinerja keuangan adalah suatu analisis yang dilakukan untuk melihat sejauh mana suatu perusahaan telah melaksanakan operasional dengan menggunakan aturanaturan pelaksanaan keuangan secara baik dan benar (Fahmi, 2012). Untuk mengetahui pengaruh kinerja keuangan terhadap perubahan harga saham dapat dilakukan dengan cara menganalisis laporan keuangan perusahaan. Fahmi (2014) menambahkan bahwa analisis laporan keuangan dapat memberikan manfaat seperti dijadikan sebagai alat untuk menilai kinerja dan prestasi 
perusahaan, serta sebagai alat untuk mengevaluasi kondisi suatu perusahaan dari perspektif keuangan. Analisis laporan keuangan perusahaan sangat dipengaruhi oleh rasio keuangan dalam perusahaan, seperti rasio likuiditas, rasio aktivitas, rasio solvabilitas serta rasio profitabilitas (Munawir, 2010).

Penelitian yang sudah dilakukan oleh para peneliti sebelumnya telah menguji pengaruh rasio likuiditas (CR) terhadap harga saham (Puspitasari, 2018 dan Valintino, 2013), pengaruh rasio aktivitas (TATO) terhadap harga saham (Nugraha, 2016 dan Adipalguna, 2016), pengaruh rasio solvabilitas (DER) terhadap harga saham (Manoppo, 2017 dan Suryawan, 2017), dan pengaruh rasio profitabilitas (ROA) terhadap harga saham (Zuliarni, 2012; Suryawan, 2017 dan Manoppo, 2017). Secara lebih dalam, penelitian ini ingin menguji konsistensi penelitian terdahulu dengan menggunakan konteks penelitian yang berbeda yaitu pada perusahaan sub sektor properti dan real estate yang terdaftar di Bursa Efek Indonesia.

Harjito (2014) menjelaskan bahwa rasio likuiditas digunakan untuk mengukur kemampuan perusahaan dalam memenuhi kewajiban-kewajiban finansialnya yang harus segera dipenuhi atau kewajiban jangka pendek. Dalam penelitian ini rasio likuiditas yang digunakan adalah Current Ratio (CR). Variabel CR dipilih oleh peneliti karena data $\mathrm{CR}$ tersaji langsung dalam laporan keuangan perusahaan, sehingga meminimalisir terjadinya kesalahan dalam menginput atau mengolah data dibandingkan dengan menggunakan variabel selain CR. Munawir (2005) mengatakan bahwa $\mathrm{CR}$ merupakan rasio yang umum digunakan untuk menggambarkan modal kerja perusahaan yang menunjukkan kemampuan perusahaan membayar hutang jangka pendek.

Harahap (2010) menjelaskan bahwa Current Ratio menunjukkan kemampuan perusahaan mendanai operasionalnya dan melunasi kewajiban jangka pendek. Suatu keadaan kelebihan aktiva lancar yang besar atas kewajiban lancar tampaknya membantu melindungi klaim, karena persediaan dapat dicairkan dengan pelelangan atau karena tidak terdapat banyak masalah dalam penagihan piutang usaha. Jika hutang lancar melebihi aktiva lancar yang dimiliki perusahaan, berarti perusahaan tidak mampu menanggung tagihan hutang jangka pendeknya.

Beberapa penelitian terdahulu yang dilakukan oleh Valintino (2013) dan Adipalguna (2016) menunjukkan hasil bahwa Current Ratio (CR) berpengaruh positif terhadap harga saham. Sesuai dengan teori sinyal yang dikemukakan Brigham (2012) bahwa ketika rasio likuiditas perusahaan meningkat, maka akan memicu kenaikan permintaan saham oleh investor, sehingga harga saham juga akan meningkat di pasar modal.

Bringham (2013) menyatakan bahwa rasio solvabilitas merupakan rasio yang mengukur sejauh mana perusahaan menggunakan pendanaan melalui hutang (financial leverage). Kasmir (2012) menambahkan bahwa rasio solvabilitas adalah rasio yang digunakan untuk mengukur sejauh mana aktiva perusahaan dibiayai dengan hutang. Artinya, seberapa besar beban hutang yang ditanggung perusahaan dibandingkan dengan aktiva yang dimiliki. Dalam arti luas dikatakan bahwa rasio solvabilitas digunakan untuk mengukur kemampuan perusahaan untuk membayar seluruh kewajibannya, baik jangka pendek maupun jangka panjang apabila perusahaan dibubarkan (likuidasi). 
Rasio solvabilitas yang digunakan dalam penelitian ini adalah Debt to Equity Ratio (DER). Variabel DER dipilih oleh peneliti karena memberikan gambaran sebesapa besar perbandingan modal perusahaan dengan hutang yang dimiliki, sehingga ketika nilainya tinggi, maka komposisi hutang juga tinggi dan akan menurunkan tingkat pengembalian kepada investor yang kemudian juga akan menurunkan harga saham perusahaan tersebut. Sutrisno (2012) menjelaskan bahwa semakin tinggi rasio ini berarti modal sendiri semakin sedikit dibanding dengan hutangnya. Apabila rasionya tinggi, maka investor akan merasa khawatir jika perusahaan tidak mampu memenuhi kewajibannya dan menanggung resiko atas hutang perusahaan. Ketika investor merasa khawatir, maka akan memicu penurunan permintaan terhadap saham perusahaan tersebut, sehingga harga saham juga ikut menurun. Hal tersebut sejalan dengan teori sinyal yang dikemukakan Brigham (2012) ketika permintaan saham menurun, maka harga saham di pasar modal juga ikut menurun.

Penelitian terdahulu yang dilakukan oleh Valintino (2013) dan Nugraha (2016) menunjukkan bahwa variabel Debt to Equity Ratio (DER) berpengaruh negatif terhadap harga saham. Variabel DER berpengaruh negatif terhadap harga saham karena apabila rasio ini tinggi, maka hal ini menggambarkan bahwa perusahaan menggunakan hutang lebih banyak dari pada aktivanya.

Sutrisno (2012) menyatakan bahwa rasio profitabilitas menggambarkan kemampuan perusahaan dalam menghasilkan keuntungan dengan semua modal yang bekerja di dalamnya. Bringham (2013) menambahkan bahwa rasio profitabilitas merupakan sekelompok rasio yang menunjukkan kombinasi dari pengaruh rasio likuiditas, manajemen aset dan hutang pada hasil operasi. Rasio profitabilitas yang digunakan dalam penelitian ini adalah Return On Assets (ROA). Variabel ROA dipilih oleh peneliti karena dapat mengetahui posisi perusahaan terhadap industri. Hal ini merupakan salah satu langkah dalam perencanaan strategi (Munawir, 2001). Selain itu, ROA dapat mengukur efisiensi penggunaan modal yang menyeluruh, yang sensitif terhadap setiap hal yang mempengaruhi keadaan keuangan perusahaan (Munawir, 2001).

Lestari (2007) menjelaskan bahwa ROA digunakan untuk mengukur keuntungan bersih yang diperoleh dari penggunaan aktiva. Dengan kata lain, semakin tinggi rasio ini maka semakin baik produktivitas aset dalam memperoleh keuntungan bersih. Hal ini selanjutkan akan meningkatkan daya tarik perusahaan kepada investor. Peningkatan daya tarik perusahaan tersebut akan semakin diminati investor, karena tingkat pengembalian (return) akan semakin besar, sehingga minat investor juga bertambah. Sesuai teori sinyal yang dikemukakan Brigham (2012) bahwa dengan meningkatnya minat investor terhadap saham sebuah perusahahaan, maka akan berdampak harga saham dari perusahaan tersebut di pasar modal juga meningkat.

Penelitian terdahulu yang telah dilakukan oleh Suryawan (2017) dan Manoppo (2017) menunjukkan hasil bahwa rasio profitabilitas yang diukur dengan Return On Asset (ROA) berpengaruh positif terhadap harga saham. Variabel ROA berpengaruh positif terhadap harga saham, karena mampu memberikan gambaran laba yang diperoleh perusahaan dari penggunaan aktivanya sehingga pada akhirnya dapat menarik minat investor untuk menanam sahamdan diikuti dengan harga saham perusahaan yang juga ikut meningkat. 
Harahap (2009) menjelaskan bahwa rasio aktivitas adalah rasio yang menggambarkan aktivitas yang dilakukan perusahaan dalam menjalankan operasionalnya baik dalam kegiatan penjualan, pembelian dan kegiatan lainnya. Dalam penelitian ini rasio aktivitas yang peneliti gunakan yaitu Total Assets Turn Over (TATO). Variabel TATO dipilih oleh peneliti karena dapat menggambarkan bahwa perusahaan mengelola asetnya secara efektif, mampu mengelola dana yang ada pada perusahaan untuk kegiatan operasionalnya, dan hal tersebut menjadi salah satu daya tarik bagi inverstor untuk menanamkan sahamnya. Ketika daya tarik investor bertambah, maka harga saham perusahaan di pasar modal juga ikut meningkat. Harahap (2009) mengatakan bahwa semakin besar rasio ini maka semakin baik, karena perusahaan tersebut dianggap efektif dalam mengelola asetnya. Beberapa penelitian terdahulu yang telah dilakukan oleh Maria (2014) dan Adipalguna (2016) menunjukkan bahwa variabel TATO berpengaruh positif terhadap saham.

Teori yang digunakan dalam menjelaskan pengaruh kinerja keuangan terhadap harga saham, mengacu pada teori sinyal (signaling theory) yang menjelaskan tentang tindakan yang diambil oleh manajemen perusahaan untuk memberikan petunjuk kepada para investor mengenai bagaimana cara pandang manajemen terhadap prospek perusahaan (Brigham, 2012). Teori ini memiliki makna informasi maupun sinyal untuk memprediksi keadaan perusahaan dimasa yang akan datang. Pemberian signal mengenai kinerja keuangan diharapkan dapat menarik para investor untuk berinvestasi pada perusahaan dengan menggunakan laporan keuangan sebagai bahan pertimbangan.

Analisis laporan keuangan terdiri dari beberapa rasio keuangan dan apabila hasil analisis laporan keuangan menunjukkan kinerja perusahaan yang baik, akan meningkatkan permintaan saham oleh investor sehingga harga saham perusahaan juga akan meningkat di pasar modal. Sebaliknya, jika permintaan saham rendah, maka harga saham akan ikut menurun di pasar modal (Brigham, 2012).

Dalam penelitian ini, peneliti akan menganalisis pengaruh kinerja keuangan terhadap harga saham dengan objek penelitian perusahaan sub sektor properti dan real estate yang terdaftar di Bursa Efek Indonesia tahun pengamatan 20152017. Peneliti tertarik untuk meneliti pada perusahaan sub sektor properti dan real estate dengan beberapa alasan.

Pertama, penelitian yang menguji pengaruh kinerja keuangan terhadap harga saham perusahaan sub sektor properti dan real estate pada periode pengamatan tahun 2015-2017 belum pernah diteliti oleh peneliti terdahulu. Kedua, perusahaan sub sektor properti dan real estate merupakan salah satu sub sektor terbesar dalam sektor bidang jasa yang terdaftar di Bursa Efek Indonesia dengan total jumlah 48 perusahaan dan belum pernah diteliti oleh peneliti terdahulu yang fokus pada obyek penelitian sektor industri barang konsumsi (Manoppo, 2017), sektor keuangan (Puspitasari, 2018) dan sektor industri dasar \& kimia (Nugraha, 2016), sehingga penelitian ini menarik diteliti. Ketiga, data kependudukan yang menggambarkan pertumbuhan serta laju pertumbuhan penduduk menunjukkan peningkatan dari tahun 2010 hingga 2017. Data pertumbuhan dan laju pertumbuhan penduduk menunjukkan jumlah penduduk Indonesia semakin bertambah setiap tahun dan laju pertumbuhannya juga meningkat.

Tujuan dari penelitian ini adalah: 1) untuk mengetahui pengaruh positif current ratio terhadap harga saham, 2) untuk mengetahui pengaruh negatif debt to 
equity ratio terhadap harga saham, 3) untuk mengetahui pengaruh positif return on asset terhadap harga saham dan 4) untuk mengetahui pengaruh positif total asset turn over terhadap harga saham.

\section{REVIEW LITERATUR DAN HIPOTESIS}

\section{Landasan Teori}

1. Manajemen Keuangan Menurut Harjito (2014) manajemen keuangan (Financial Management) atau dalam literatur lain disebut pembelanjaan adalah segala aktivitas perusahaan yang berhubungan dengan bagaimana memperoleh dana, menggunakan dana, dan mengelola aset sesuai tujuan. Syamsuddin (2007) menambahkan bahwa manajemen keuangan menekankan pada penerapan prinsip-prinsip ekonomi dalam mengelola keputusan-keputusan yang menyangkut masalah finansial perusahaan. Fungsi manajemen keuangan dalam suatu perusahaan terdiri atas keputusan investasi, keputusan pendanaan, dan keputusan pengelolaan.

Pendapat lain yang dikemukakan oleh Kasmir (2010) menyatakan bahwa manajemen keuangan adalah segala aktivitas yang berhubungan dengan perolehan, pendanaan, dan pengelolaan aktiva dengan beberapa tujuan menyeluruh. Dari beberapa pendapat ahli di atas, dapat disimpulkan bahwa manajemen keuangan merupakan manajemen (pengelolaan) mengenai bagaimana memperoleh aset, mendanai aset dan mengelola aset untuk mencapai tujuan perusahaan.

\section{Saham Dan Harga Saham}

Siamat (2005) mengatakan saham adalah tanda penyertaan atau tanda kepemilikan bagian modal seseorang atau badan usaha pada sebuah perusahaan. Wujud saham adalah selembar kertas yang menerangkan bahwa pemilik kertas tersebut merupakan pemilik perusahaan yang menerbitkan surat berharga. Ketika perusahaan mengalami kebangkrutan, maka kas yang ada dipakai untuk melunasi utang terlebih dahulu, baru kemudian jika terdapat sisa kas, digunakan untuk membayar pemegang saham. Dari pengertian di atas, dapat disimpulkan bahwa saham merupakan surat berharga yang diperjual belikan dalam pasar modal, dimana pemegang saham memiliki hak atas perundapatan dari perusahaan.

Darmadji (2012) menjelaskan harga saham adalah harga yang terjadi di bursa pada waktu tertentu. Harga saham bisa berubah naik atau turun dalam hitungan waktu yang begitu cepat. Harga saham dapat berubah dalam hitungan menit bahkan dalam hitungan detik. Hal tersebut dimungkinkan karena tergantung dengan permintaan dan penawaran antara pembeli saham dengan penjual saham. Setiyawan (2014) menambahkan harga saham yang diharapkan oleh investor adalah harga saham yang stabil dan mempunyai pola pergerakan yang cenderung naik dari waktu ke waktu. Akan tetapi, kenyataannya harga saham cenderung fluktuasi. Berfluktuasinya harga saham menjadi risiko tersendiri bagi investor. Oleh karena itu investor harus memahami hal apa saja yang dapat mempengaruhi fluktuasi harga saham.

Dari pengertian di atas, dapat disimpulkan bahwa harga saham adalah harga dari suatu saham yang ditentukan pada saat pasar saham berlangsung yang dipengaruhi oleh permintaan dan penawaran.

\section{Teori Sinyal (Signaling Theory)}

Spence (1973) menyatakan bahwa isyarat atau signal memberikan suatu sinyal, pihak pengirim (pemilik 
informasi) berusaha memberikan potongan infomasi relevan yang dapat dimanfaatkan oleh pihak penerima. Pihak penerima kemudian akan menyesuaikan perilakunya sesuai dengan pemahamannya terhadap sinyal tersebut. Signaling Theory menurut Brigham (2012) menjelaskan tentang tindakan yang diambil oleh manajemen perusahaan untuk memberikan petunjuk kepada para investor mengenai bagaimana cara pandang manajemen terhadap prospek perusahaan. Jama'an (2008) menambahkan bahwa Signaling Theory mengemukakan tentang bagaimana seharusnya sebuah perusahaan memberikan sinyal kepada pengguna laporan keuangan. Sinyal ini berupa informasi mengenai apa yang sudah dilakukan manajemen untuk merealisasikan keinginan pemilik. Sinyal dapat berupa promosi atau informasi lain yang menyatakan bahwa perusahaan tersebut lebih baik dari pada perusahaan lainnya.

\section{Analisis Rasio Keuangan}

Menurut Kasmir (2015) analisis rasio keuangan merupakan indeks yang menghubungkan dua angka akuntansi dan diperoleh dengan membagi satu angka dengan angka lainnya. Dari hasil rasio keuangan akan terlihat kondisi keuangan dan kinerja perusahaan yang bersangkutan. Analisis keuangan yang mencakup analisis rasio keuangan, analisis kelemahan dan kekuatan di bidang finansial akan sangat membantu dalam menilai prestasi manajemen masa lalu dan prospeknya di masa depan (Sartono, 2001).

Sementara Harjito (2014) menambahkan bahwa analisis rasio keuangan dapat dibedakan berdasarkan laporan keuangan yang dianalisis, yaitu analisis secara individual dan analisis silang. Analisis individual dimaksudkan sebagai analisis yang dilakukan pada unsur-unsur yang ada pada salah satu laporan keuangan. Sedangkan analisis silang merupakan analisis rasio yang melibatkan unsur-unsur yang ada pada laporan neraca dan sekaligus yang ada pada laba rugi. Unsur-unsur yang ada pada kedua laporan tersebut digabungkan untuk mendapatkan suatu rasio keuangan tertentu.

Rasio keuangan menurut Harahap (2013) merupakan angka yang diperoleh dari hasil perbandingan dari suatu pos laporan keuangan dengan pos lainnya yang mempunyai hubungan yang relevan dan signifikan. Pada umumnya, analisis rasio keuangan (Financial Ratio Analysis) terdapat beberapa jenis yaitu Rasio Profitabilitas, Rasio Likuiditas, Rasio Solvabilitas, dan Rasio Aktivitas.

\section{Penelitian Terdahulu}

Berikut ini adalah hasil penelitian terdahulu yang pernah dilakukan oleh beberapa pihak dan memiliki beberapa kesamaan seperti yang penulis teliti saat ini.

1. Manoppo, Vera Ch. O., dkk (2017) melakukan penelitian dengan judul "Pengaruh CR, DER, ROA dan NPM Terhadap Harga Saham Pada Perusahaan Food And Baverages Yang Terdaftar Di BEI Periode 2013-2015". Dari penelitian tersebut, diperoleh hasil sebagai berikut:

a. Current Ratio (CR), Debt to Equity Ratio (DER), Return On Asset (ROA), dan Net Profit Margin (NPM) secara simultan berpengaruh signifikan terhadap Harga Saham.

b. Current Ratio (CR) berpengaruh negatif dan tidak signifikan terhadap Harga Saham.

c. Debt to Equity Ratio (DER) berpengaruh negatif dan tidak signifikan terhadap Harga Saham.

d. Return On Asset (ROA) berpengaruh positif dan signifikan terhadap Harga Saham. 
e. Net Profit Margin (NPM) berpengaruh negatif dan signifikan terhadap Harga Saham.

2. Suryawan, I Dewa Gede dan I Gede Ary Wirajaya (2017) melakukan penelitian dengan judul "Pengaruh Current Ratio, Debt to Equity Ratio Dan Return On Assets Pada Harga Saham”. Dari penelitian tersebut, diperoleh hasil sebagai berikut:

a. Current Ratio berpengaruh negatif terhadap harga saham perusahaan LQ45 di Bursa Efek Indonesia

b. Debt to Equity Ratio berpengaruh negatif terhadap harga saham perusahaan LQ45 di Bursa Efek Indonesia

c. Return On Asset berpengaruh positif terhadap harga saham perusahaan LQ45 di Bursa Efek Indonesia

3. Puspitasari, Meilia Arum (2018) melakukan penelitian dengan judul "Analisis Pengaruh Rasio CR, ROA dan DER Terhadap Harga Saham (Studi Kasus Pada Perbankan Umum Go Public Yang Terdaftar di BEI Periode 2013-2015)". Dari penelitian tersebut, diperoleh hasil sebagai berikut:

a. Current Ratio berpengaruh negatif dan signifikan terhadap Harga Saham (Studi Kasus Pada Perbankan Umum Go Public Yang Terdaftar di BEI Periode 2013-2015).

b. Return On Asset berpengaruh positif dan signifikan terhadap Harga Saham (Studi Kasus Pada Perbankan Umum Go Public Yang Terdaftar di BEI Periode 2013-2015).

c. Debt to Equity Ratio berpengaruh negatif dan signifikan terhadap Harga Saham (Studi Kasus Pada Perbankan Umum Go Public Yang Terdaftar di BEI Periode 20132015).

d. Current Ratio, Return On Asset, Debt to Equiry Ratio berpengaruh signifikan terhadap Harga Saham (Studi Kasus Pada Perbankan Umum
Go Public Yang Terdaftar di BEI Periode 2013-2015).

\section{Hipotesis}

H1: Current Ratio (CR) berpengaruh positif terhadap harga saham.

H2: Debt to Equity Ratio (DER) berpengaruh negatif terhadap harga saham.

H3: Return On Asset (ROA) berpengaruh positif terhadap harga saham.

H4: Total Asset Turn Over (TATO) berpengaruh positif terhadap harga saham.

\section{METODE PENELITIAN}

\section{Populasi}

Populasi adalah kumpulan dari beberapa unit yang menjadi objek penelitian dengan berbagai macam karateristik dan kualitas tertentu, yang kemudian akan diolah untuk menghasilkan kesimpulan atas penelitian tersebut. Menurut Suharyadi (2009) menyatakan populasi adalah kumpulan dari semua kemungkinan orang-orang, benda-benda, dan ukuran lain, yang menjadi objek perhatian atau kumpulan seluruh objek yang menjadi perhatian.

Di dalam penelitian ini, populasinya adalah seluruh perusahaan yang bergerak di bidang sub sektor properti dan real estate dan terdaftar di Bursa Efek Indonesia (BEI) pada periode 2015-2017, yakni berjumlah 48 perusahaan.

\section{Teknik Pengambilan Sampel}

Di dalam penelitian ini, teknik pengambilan sampel yang peneliti gunakan adalah dengan metode purposive sampling. Alasan peneliti menggunakan metode purposive sampling yaitu dengan jumlah populasi perusahaan yang cukup banyak, akan diperoleh sampel perusahaan yang akan menjadi bahan penelitian yang sesuai dengan kriteria-kriteria tertentu 
yang penulis tetapkan dalam penelitian ini. Menurut Supomo (2002), mengatakan melalui metode purposive sampling, yang merupakan metode pemilihan sampel tidak secara acak yang informasinya diperoleh dengan menggunakan pertimbangan tertentu dimana perusahaan dipilih berdasarkan kriteria-kriteria tertentu untuk mendapatkan sampel yang representatif.

Adapun kriteria yang penulis tetapkan sebagai berikut:

1. Perusahaan sub sektor properti dan real estate yang terdaftar di Bursa Efek Indonesia pada periode 20152017.

2. Perusahaan sub sektor properti dan real estate yang menyampaikan laporan data keuangan pada periode 2015-2017.

3. Perusahaan sub sektor properti dan real estate yang mempunyai laporan laba bersih positif pada periode 2015-2017.

\section{Deskripsi Variabel Penelitian}

Di dalam penelitian ini, terdapat 2 variabel penelitian, yaitu dependen dan independen. Variabel dependen dalam penelitian ini adalah harga saham, sementara variabel independennya yaitu rasio likuiditas (CR), rasio solvabilitias (DER), rasio profitabilitas (ROA) dan rasio aktivitas (TATO).

1. Variabel Dependen

$$
\text { Variabel dependen dalam }
$$
penelitian ini adalah harga saham yang diambil pada masa penutupan sesuai dengan tahun periode pengamatan yakni tahun 2015-2017. Sedangkan menurut Sartono (2008) menyatakan harga saham terbentuk melalui mekanisme permintaan dan penawaran pasar modal. Apabila suatu saham mengalami kelebihan permintaan, maka harga saham cenderung naik.
Sebaliknya, apabila kelebihan penawaran maka harga saham cenderung menurun.

Berdasarkan pendapat dari beberapa ahli di atas, dapat disimpulkan bahwa harga saham merupakan harga yang terbentuk atas adanya aktivitas permintaan dan penawaran terhadap saham di bursa jual beli saham.

2. Variabel Independen

Variabel independen dalam penelitian ini adalah rasio keuangan, diantaranya rasio likuiditas, rasio solvabilitas, rasio profitabilitas dan rasio aktivitas.

a. Rasio Likuiditas merupakan rasio yang menunjukkan hubungan antar kas perusahaan dan aktiva lancar lainnya dengan hutang lancar. Rasio likuiditas digunakan untuk mengukut kemampuan perusahaan dalam memenuhi kewajiban finansialnya yang harus segera dipenuhi atau kewajiban jangka pendek. Jenis rasio likuiditas yang peneliti gunakan dalam penelitian ini yaitu Current Ratio (CR) yang merupakan perbandingan antara aktiva lancar yang terdiri dari kas, surat berharga, piutang, dan persediaan dengan hutang lancar terdiri dari hutang dagang, dan hutang jangka pendek lainnya.

$$
\begin{aligned}
& \mathrm{CR}=(\text { Aktiva Lancar / Hutang } \\
& \text { Lancar) } \times 100 \%
\end{aligned}
$$

b. Rasio Solvabilitas merupakan rasio yang digunakan untuk mengukur kemampuan perusahaan untuk membayar hutang pada saat perusahaan dilikuidasi atau dibubarkan. Jenis rasio solvabilitas yang peneliti gunakan dalam penelitian ini yaitu Debt to Equity Ratio (DER) yang merupakan rasio perbandingan antara jumlah 
keseluruhan hutang dengan jumlah keseluruhan modal yang dimiliki perusahaan.

DER $=$ Total Hutang $/$ Total Modal

c. Rasio Profitabilitas merupakan rasio yang digunakan untuk mengukur kemampuan perusahaan dalam menghasilkan laba atau mengukur efektivitas manajemen dalam menghasilkan keuntungan dari penjualan dan investasi. Dalam penelitian ini, jenis rasio profitabilitas yang digunakan adalah Return On Asset (ROA). ROA menggambarkan perbandingan laba bersih setelah pajak dengan total asset yang dimiliki oleh perusahaan. ROA = Laba Usaha /Total Aktiva

d. Rasio Aktivitas adalah rasio yang mengukur sejauh mana efektivitas manajemen perusahaan dalam mengelola asetnya. Artinya dalam hal ini adalah mengukur kemampuan manajemen perusahaan dalam mengelola persediaan serta kebijakan manajemen dalam mengelola aktiva lainnya dan kebijakan pasar. Menurut Harahap (2009) menjelaskan bahwa rasio aktivitas adalah rasio yang menggambarkan aktivitas yang dilakukan perusahaan dalam menjalankan operasinya baik dalam kegiatan penjualan, pembelian dan kegiatan lainnya. Dalam penelitian ini, jenis rasio yang digunakan adalah Total Asset Turn Over (TATO) yang mengukur perputaran dari semua asset yang dimiliki perusahaan yang diperoleh dari hitungan pembagian antara penjualan dengan total asetnya.

TATO $=$ Penjualan Bersih $/$ Total Asset

\section{Teknik Analisis Data}

1. Uji Analisis Deskriptif

Analisis deskriptif dilakukan untuk mengetahui gambaran seluruh variabel dalam penelitianyang menunjukkan hasil pengujian untuk nilai minimum (Min), maksimum (Max), mean, dan Standar Deviation (SD).

\section{Uji Asumsi Klasik}

a. Uji Normalitas

Uji normalitas bertujuan untuk menguji apakahdalam modelregresi, variabel dependen dan independen keduanya berdistribusi normal atau tidak (Ghozali, 2011). Pengujian ini dilakukan dengan uji Jarque-Bera. Kriteria dalam penilaian uji ini apabila nilai probabilitas J-B lebih besar dari alpha 5\% (prob. J-B > 0,05), maka data berdistribusi normal (Kusuma, 2012).

b. Uji Autokorelasi

Autokorelasi adalah hubungan antara residual satu observasi dengan observasi lainnya (Kusuma, 2012). Keputusan yang diambil ketika menggunakan uji ini adalah:

Jika Prob. Chi Square > 0,05, maka tidak ada autokorelasi

Jika Prob. Chi Square < 0,05, maka ada autokorelasi

c. Uji Multikolinieritas

Multikolinieritas merupakan salah satu masalah dalam analisis regresi dengan OLS, yang berarti terdapat korelasi atau hubungan yang sangat tinggi diantara variabel independen. Multikolinieritas hanya terjadi pada regresi majemuk, karena melibatkan beberapa variabel independen sehingga tidak terjadi pada regresi sederhana (Kusuma, 2012). 
Pengujian korelasi antar variabel independen dapat dikatanya adanya gejala multikolinieritas apabila variabel independen saling berkorelasi lebih dari 0,90 (>90\%).

\section{d. Uji Heteroskedastisitas}

Uji heteroskedastisitas adalah uji untuk mengetahui kondisi dimana nilai varians error untuk setiap data pengamatan tidak konstan (Kusuma, 2012). Dalam penelitian ini, peneliti menggunakan metode BreuschPagan-Godfrey (BPG), dimana metode ini memerlukan pengurutan dan penghilangan data. Keputusan yang diambil dalam pengujian ini adalah sebagai berikut:

Jika Prob. Chi Square (p-value) > 0,05 , maka tidak terjadi heteroskedastisitas

Jika Prob. Chi Square (p-value) < 0,05, maka terjadi heteroskedastisitas

\section{Analisis Regresi Data Panel}

Teknik analisisregresi data panel merupakan gabungan antara data silang (cross section) dengan data runtut waktu (time series). Data cross section terdiri dari beberapa objek, sedangkan data time series biasanya hanya satu objek tapi meliputi beberapa periode (Kusuma, 2012). Ada dua teknik dalam melakukan analisis regresi data panel:

a. Uji Chow

Uji chow ini untuk menentukan apakah menggunakan metode common effect atau metode fixed effect, dengan pertimbangan:

Jika Prob. Chi square <0,05, maka fixed effect

Jika Prob. Chi Square > 0,05, maka common effect

Bila hasil menunjukkan common effect, maka penentuan model berhenti sampai disini. Akan tetapi, jika hasil menunjukkan model fixed effect, maka harus dilanjut dengan metode random effect dengan uji Hausman.

b. Uji Hausman

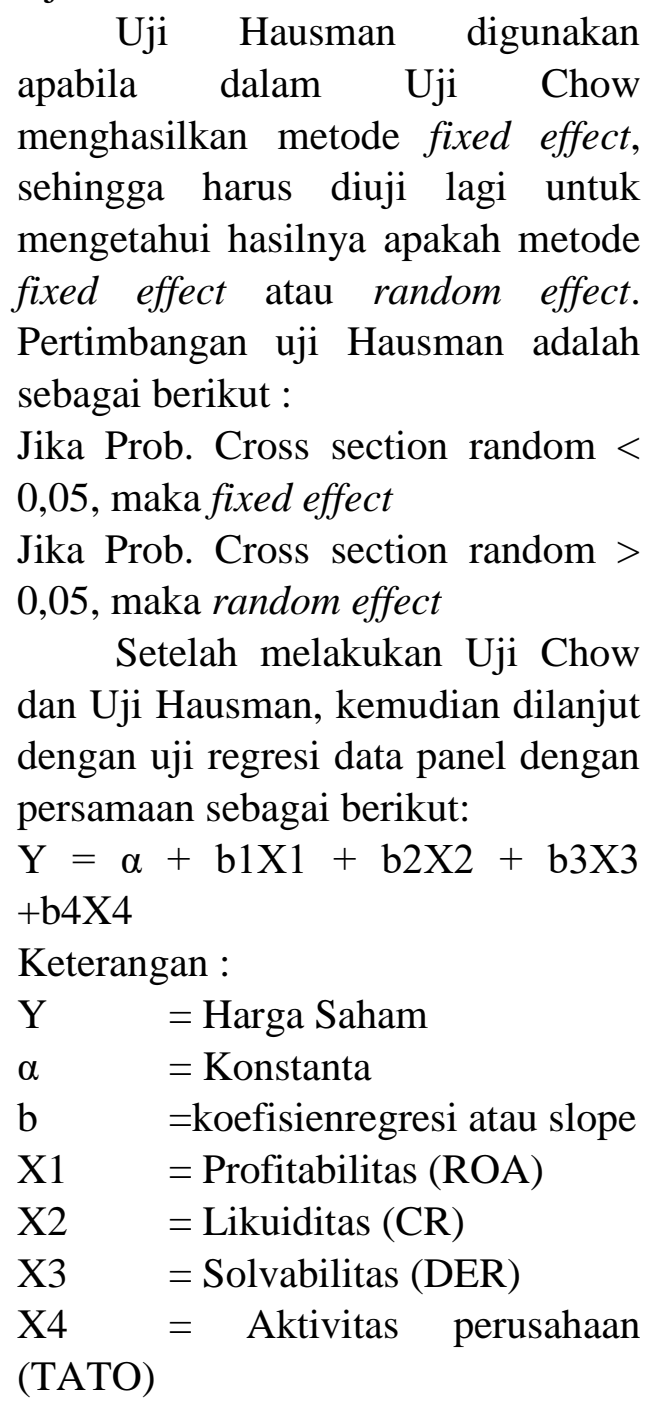

4. Uji Model

a. Uji Simultan (Uji F)

Uji yang digunakan untuk mengetahui apakah variabel independen yang dimasukkan dalam model mempunyai pengaruh secara simultan terhadap variabel dependen (Ghozali, 2011). Kriteria dalam uji F menunjukkan :

Jika nilai Prob. (F-Statistic) $<0,05$, maka seluruh variabel independen 
secara simultan berpengaruh signifikan terhadap variabel dependen.

Jika nilai Prob. (F-Statistic) $>0,05$, maka seluruh variabel independen secara simultan tidak berpengaruh signifikan terhadap variabel dependen.

b. Uji Koefisien Determinasi (R2)

Uji ini digunakan untuk mengukur seberapa jauh kemampuan model regresi dalam menjelaskan variasi variabel dependen (Ghozali, 2011). Nilai koefisien determinasi besarnya antara 0 (nol) dan 1 (satu). Apabila nilai R2 mendekati 0, maka kemampuan variabel independen dalam menjelaskan variabel dependen masih terbatas. Sebaliknya, jika nilai R2 mendekati 1, maka kemampuan variabel independen dalam menjelaskan variabel dependen cukup baik.

c. Uji Parsial (Uji T)

Uji parsial digunakan untuk mengetahui pengaruh dari masingmasing variabel independen terhadap variabel dependen. Kriteria dalam uji $\mathrm{T}$ ini adalah sebagai berikut :

Jika nilai probabilitas $<0,5$, maka variabel independen berpengaruh signifikan terhadap variabel dependen.

Jika nilai probabilitas > 0,05 , maka variabel independen berpengaruh tidak signifikan terhadap variabel dependen.

\section{HASIL PENELITIAN DAN PEMBAHASAN}

\section{Hasil Penelitian}

1. Hasil Uji Analisis Deskriptif

Hasil Lji Analisis Deskriptif

\begin{tabular}{|c|c|c|c|c|c|}
\hline & CR & DER & R0A & TAT0 & HARGA \\
\hline Mean & 223,449 & 6,867 & 10,750 & 0,210 & 2116,961 \\
\hline Maximum & 1166,380 & 624,960 & 463,000 & 0,520 & 36500,000 \\
\hline Minimum & 0,000 & 0,060 & 0,030 & 0,010 & 50,000 \\
\hline Std. Dev. & 245,357 & 61,808 & 45,588 & 0,093 & 4990,904 \\
\hline
\end{tabular}

a. Current Ratio (CR)

Nilai minimum $\mathrm{CR}$ sebesar 0,000 terdapat pada perusahaan Bekasi Asri Pemula Tbk tahun 2015 hingga 2017, dan nilai maksimum sebesar 1166,380 terdapat pada perusahaan Agung Podomoro Land Tbk tahun 2017. Hal ini menunjukkan besarnya Current Ratio perusahaan yang menjadi sampel dalam penelitian ini berkisar antara 0,000 sampai 1166,380, dengan nilai rata-rata sebesar 223,449 dan standar deviasi sebesar 245,357.

b. Debt to Equity Ratio (DER)

Nilai minimum DER sebesar 0,060 terdapat pada perusahaan Puradelta Lestari Tbk tahun 2016 dan nilai maksimum sebesar 624,960 terdapat pada perusahaan Metropolitan Land Tbk tahun 2017. Hal ini menunjukkan besarnya Debt to Equity Ratio perusahaan yang menjadi sampel dalam penelitian ini berkisar antara 0,060 sampai 624,960 , dengan nilai rata-rata sebesar 6,867 dan standar deviasi sebesar 61,808 . 
c. Return On Assets (ROA)

Nilai minimum ROA sebesar 0,030 terdapat pada perusahaan Gading Development Tbk tahun 2017 dan nilai maksimum sebesar 463,000 terdapat pada perusahaan Perdana Gapuraprima Tbk tahun 2015. Hal ini menunjukkan besarnya Return On Assets perusahaan yang menjadi sampel dalam penelitian ini berkisar antara 0,030 sampai 463,000 , dengan nilai rata-rata sebesar 10,758 dan standar deviasi sebesar 45,588.

d. Total Asset Turn Over (TATO)

Nilai minimum TATO sebesar 0,010 terdapat pada perusahaan Greenwood Sejahtera Tbk tahun 2015 dan nilai maksimum sebesar 0,520 terdapat pada perusahaan Fortune Mate Indonesia Tbk tahun 2016. Hal ini menunjukkan besarnya Total Assets Turn Over perusahaan yang menjadi sampel dalam penelitian ini berkisar antara 0,010 sampai 0,520 , dengan nilai rata-rata sebesar 0,210 dan standar deviasi sebesar 0,093.

e. Harga Saham

Nilai minimum harga saham sebesar 50,000 terdapat pada 2 perusahaan, yakni Bekasi Asri Pemula Tbk tahun 2015 dan 2016, serta Gading Development Tbk tahun 2016. Nilai maksimum harga saham terdapat pada perusahaan Metropolitan Kentjana Tbk sebesar 36500,00 pada tahun 2017. Hal ini menunjukkan besarnya harga saham perusahaan yang menjadi sampel dalam penelitian ini berkisar antara 50,000 sampai 36500,00 , dengan nilai rata-rata sebesar 2116,961 dan standar deviasi sebesar 4970,904.
2. Hasil Uji Asumsi Klasik

a. Uji Normalitas

\section{Hasil Lji Normalitas}

\begin{tabular}{|c|c|}
\hline Keterangan & Prob. \\
\hline Uji Jarque-Bera & 0,068506 \\
\hline
\end{tabular}

Dari hasil uji normalitas Jarque-Bera menunjukkan probabilitas J-B sebesar 0,068506. Artinya, data penelitian tersebut berdistribusi normal, karena nilai probabilitas Jarque-Bera lebih besar dari $5 \%(0,068506>0,05)$.

b. Uji Autokorelasi

Hasil Lji Autokorelasi

\begin{tabular}{|c|c|}
\hline Keterangan & Prob. \\
\hline Uji Bretsch-Godfrey & 0,2332 \\
& \\
\hline
\end{tabular}

Dari hasil uji autokorelasi dengan metode Breusch-Godfrey, diperoleh nilai prob. chi square sebesar 0,2332. Artinya, data tersebut tidak mengandung masalah autokorelasi, karena nilai prob. chi square lebih besar dari 5\% (0,2332 > $0,05)$.

c. Uji Heteroskedastisitas Hasil Lji Heteroskedastisitas

\begin{tabular}{|c|c|}
\hline Keterangan & Prob. \\
\hline UjiBreusch-Pagan-Godfrey & 0,0728 \\
$(\mathrm{BPG})$ & \\
\hline Dari & hasil uji \\
\hline
\end{tabular}

heteroskedastisitas, diperoleh nilai prob. chi square sebesar 0,0728. Artinya, data yang digunakan 
terbebas dari masalah heteroskedastisitas, dengan nilai prob. chi square $>0,05$.

d. Uji Multikolinieritas Hasil Lji Multikolinieritas

\begin{tabular}{|c|c|c|}
\hline Variabel & Variabel & Korelasi \\
\hline$C R$ & DER & 0,012050 \\
\hline$C R$ & ROA & $-0,076884$ \\
\hline$C R$ & TAT0 & 0,021370 \\
\hline DER & ROA & 0,000893 \\
\hline DER & TAT0 & 0,055658 \\
\hline ROA & TAT0 & 0,131839 \\
\hline
\end{tabular}

Berdasarkan tabel diatas, dapat dilihat bahwa nilai korelasi (derajat keeratan) yang rendah, yakni kurang dari $90 \%$ (korelasi < 0,90). Hal tersebut menunjukkan bahwa tidak ada korelasi atau hubungan antar variabel independennya, sehingga tidak terdapat adanya gejala multikolinieritas.

3. Hasil Analisis Regresi Data Panel a. Uji Chow

\section{Hasil Ljichow}

\begin{tabular}{|c|c|c|c|}
\hline Keterangan & Test & Prob. & Kesimpulan \\
\hline Ujichow & Cross-Section & 0,000 & Fixed Effect \\
& Fixed & & \\
\hline
\end{tabular}

Tabel di atas menunjukkan nilai probabilitas chi square 0,000 yang mana kurang dari 0,05 , sehingga dapat ditarik kesimpulan bahwa metode fixed Effect yang terpilih. Selanjutnya, karena metode fixed effect yang terpilih, maka dilanjutkan dengan menggunakan uji Hausman untuk membandingkan dengan metode fixed effect metode random effect.

b. Uji Hausman Hasil Uji Hausman

\begin{tabular}{|c|c|c|c|}
\hline Keterangan & Test & Prob. & Kesimpulan \\
\hline Uji Hausman & Cross-Section & 0,2699 & Random Effect \\
& Random & & \\
& & & \\
\hline
\end{tabular}

Dari hasil uji cross section random effect di atas, dapat dilihat bahwa kesimpulan yang diterima adalah metode Random Effect dengan nilai probabilitas sebesar $0,2699>0,05$.

c. Pemilihan Model Akhir

Setelah melakukan uji Chow dan uji Hausman, metode yang terpilih adalah Random Effect. Analisis regresi data panel menggunakan metode Random Effect menghasilkan regresi sebagai berikut:

Hasil Uji Regresi Data Panel Metode Random Effect

\begin{tabular}{|c|c|c|}
\hline Variabel & Coefficient & Prob. \\
\hline C & 1030,549 & 0,3966 \\
\hline CR & 0,221616 & 0,9040 \\
\hline DER & 0,145025 & 0,9679 \\
\hline R0A & $-0,448983$ & 0,9920 \\
\hline TAT0 & 4928,443 & 0,1736 \\
\hline
\end{tabular}


Persamaan model regresi:

Harga Saham = 1030,549+ $0,221616_{\mathrm{CR}}+0,145025_{\mathrm{DER}}-$ $0,048983_{\mathrm{ROA}}+4928,443_{\mathrm{TATO}}$

Penjelasan model regresi:

a. Jika rasio likuiditas (CR), rasio solvabilitas (DER), rasio profitabilitas (ROA) dan rasio aktivitas (TATO) bernilai nol (0), maka harga saham perusahaan sub sektor properti dan real estate yang terdaftar di Bursa Efek Indonesia sebesar 1030,549.

b. Rasio likuiditas (CR) bernilai 0,221616. Artinya, jika CR meningkat sebesar 1\%, maka harga saham perusahaan akan naik sebesar 0,221616. Sebaliknya, jika CR menurun sebesar $1 \%$, maka harga saham perusahaan akan turun sebesar 0,221616 .

c. Rasio solvabilitas (DER) bernilai 0,145025. Artinya, jika DER meningkat sebesar $1 \%$, maka harga saham perusahaan akan meningkat sebesar 0,145025 . Sebaliknya, jika DER menurun sebesar $1 \%$, maka harga saham perusahaan akan menurun sebesar 0,145025 .

d. Rasio profitabilitas (ROA) bernilai -0,048983. Artinya, jika ROA meningkat sebesar $1 \%$, maka harga saham perusahaan akan menurun sebesar 0,048983. Sebaliknya, jika harga saham menunrun sebesar 1\%, maka harga saham akan meningkat sebesar 0,048983.

e. Rasio aktivitas (TATO) bernilai 4928,443. Artinya, jika TATO meningkat sebesar 1\%, maka harga saham perusahaan akan meningkat 4928,443. Sebaliknya, jika TATO menurun sebesar $1 \%$, maka harga saham perusahaan akan menurun sebesar 4928,443.

\section{Hasil Uji Model}

a. Uji Parsial (Uji T)

Hasil Uji Parsial (Uji T)

\begin{tabular}{|c|c|c|c|}
\hline Variabel & Koefisien & Prob. & Kesimpulan \\
\hline C & 1030,549 & 0,3966 & \\
\hline CR & 0,221616 & 0,9040 & Berpengaruh \\
& Positif dan Tidak \\
Signifikan \\
\hline DER & 0,145025 & 0,9679 & Berpengaruh \\
\hline R0A & $-0,048983$ & 0,9920 & Berpengaruh \\
& & Positif dan Tidak \\
Signifikan \\
\hline TAT0 & 4928,443 & 0,1736 & Berpengaruh \\
& & Positif dan Tidak \\
& & Signifikan \\
\hline
\end{tabular}

Berdasarkan tabel di atas, hasil uji parsial dapat dijelaskan sebagai berikut:

\section{a. Current Ratio (CR)}

Uji hipotesis yang pertama yaitu untuk mengetahui pengaruh current ratio $(\mathrm{CR})$ terhadap harga saham. Hasil menunjukkan nilai koefisien sebesar 0,221616 yang artinya current ratio berpengaruh positif terhadap harga saham dengan nilai probabilitas sebesar 0,9040, sehingga hipotesis pertama yang mengatakan current ratio berpengaruh positif terhadap harga saham ditolak. 


\section{b. Debt to Equity Ratio (DER)}

Uji hipotesis yang kedua yaitu untuk mengetahui pengaruh debt to equity ratio (DER) terhadap harga saham. Hasil menunjukkan nilai koefisien sebesar 0,145025 yang artinya debt to equity ratio berpengaruh positif terhadap harga saham dengan nilai probabilitas sebesar 0,9679, sehingga hipotesis kedua yang mengatakan bahwa debt to equityratio berpengaruh negatif terhadap harga saham ditolak.

c. Return On Assets (ROA)

Uji hipotesis yang ketiga yaitu untuk mengetahui pengaruh return on assets (ROA) terhadap harga saham. Hasil menunjukkan nilai koefisien sebesar $-0,048983$ yang artinya return on asset berpengaruh negatif terhadap harga saham dengan nilai probabilitas sebesar 0,9920, sehingga hipotesis ketiga yang mengatakan return on assets berpengaruh positif terhadap harga saham ditolak.

\section{d. Total Asset Turn Over (TATO)}

Uji hipotesis yang keempat yaitu untuk mengetahui pengaruh total asset turn over (TATO) terhadap harga saham. Hasil menunjukkan nilai koefisien sebesar 4928,443 yang artinya total asset turn over berpengaruh positif terhadap harga saham dengan nilai probabilitas sebesar 0,1736, sehingga hipotesis keempat yang mengatakan total asset turn over berpengaruh positif terhadap harga saham ditolak. b. Uji Simultan (Uji F)

Hasil LjiSimultan (DjiF)

\begin{tabular}{|c|c|}
\hline Prob, (F.Statistic) & Kesimpulan \\
\hline 0,757421 & Tidak Berpengaruh Sigrififikan \\
\hline
\end{tabular}

Berdasarkan tabel di atas, diperoleh nilai Prob. (F-Statistic) sebesar 0.757421. Artinya, nilai prob. (F-Statistic) lebih besar dari nilai taraf signifikansi sebesar 5\% $(0.757421>0,05)$ dimana variabel CR, DER, ROA, TATO secara simultan tidak berpengaruh signifikan terhadap Harga Saham.

c. Uji Koefisien Determinasi (R2)

Hasil Lji Koefisien Determinasi ( $\left.\mathbf{R}^{2}\right)$

\begin{tabular}{|c|c|}
\hline Keterangan & Nilai R.Square \\
\hline Uji Koefisien Determinasi $\left(\mathbb{R}^{2}\right)$ & 0,019024 \\
& \\
\hline
\end{tabular}

Berdasarkan tabel di atas, nilai R2 (R-Square) yang diperoleh dari uji analisis regresi data panel sebesar 0.019024. Artinya, kemampuan variabel independen (CR, DER, ROA, TATO) dalam menjelaskan variabel dependen (Harga Saham) masih terbatas, karena nilainya hanya 0,019024 atau $1,9 \%$, sementara sisanya sebesar $98,1 \%$ dijelaskan oleh variabel lain yang tidak diuji dalam penelitian ini.

\section{Pembahasan}

1. Pengaruh Positif Rasio Likuiditas Terhadap Harga Saham

Hasil pengujian hipotesis secara parsial (Uji T) terhadap rasio likuiditas yang diukur dengan Current Ratio (CR) menunjukkan nilai koefisien sebesar 0,221616 dan nilai probabilitas sebesar 
0,9040, yang artinya current ratio berpengaruh positif dan tidak signifikan, sehingga hipotesis pertama yang mengatakan current ratio berpengaruh positif terhadap harga saham perusahaan sub sektor properti dan real estate ditolak. Hasil tersebut mendukung penelitian sebelumnya yang dilakukan oleh Suryawan (2017) dan Puspitasari (2018) dengan hasil Current Ratio (CR) berpengaruh negatif terhadap harga saham.

Menurut Harjito (2014), current ratio yang tinggi akan berpengaruh negatif terhadap kemampuan memperoleh laba (rentabilitas), karena sebagian modal kerja tidak berputar atau mengalami pengangguran. Sawir (2009) menambahkan bahwa dengan meningkatnya current ratio tidak selalu berdampak baik pada perusahaan. Current ratio yang meningkat bisa saja menunjukkan banyaknya dana yang menganggur dan pada akhirnya dapat mengurangi kemampuan perusahaan dalam memperoleh laba. Dengan demikian, investor akan menilai negatif apabila perputaran modal kerja atau dana yang ada dalam perusahaan tidak dimaksimalkan untuk memperoleh laba dari kegiatan operasionalnya.

Apabila inverstor sudah menilai negatif suatu perusahaan, maka akan berdampak pada penurunan minat dari investor dalam berinvestasi saham. Hal tersebut pada akhirnya berdampak pada penurunan harga saham perusahaan di pasar modal akibat dari penurunan minat investor. Sesuai dengan teori sinyal yang dikemukakan oleh Brigham (2012) bahwa ketika permintaan saham menurun, maka harga saham perusahaan tersebut juga ikut menurun di dalam pasar modal.
2. Pengaruh Negatif Rasio Solvabilitas Terhadap Harga Saham

Hasil pengujian hipotesis secara parsial (Uji $\mathrm{T}$ ) terhadap rasio solvabilitas yang diukur dengan Debt to Equity Ratio (DER) menunjukkan nilai koefisien sebesar 0,145025 dan nilai probabilitas sebesar 0,9679, yang artinya debt to equity ratio berpengaruh positif dan tidak signifikan, sehingga hipotesis kedua yang mengatakan bahwa debt to equity ratio berpengaruh negatif terhadap harga saham perusahaan sub sektor properti dan real estate ditolak. Hasil tersebut mendukung penelitian sebelumnya yang dilakukan oleh Novitasari (2015) dan Junaeni (2017) yang menunjukkan bahwa Debt to Equity Ratio (DER) berpengaruh positif terhadap harga saham.

Menurut Sandjaja (2003) bahwa dalam kinerja keuangan perusahaan, debt to equity ratio melibatkan akunakun yang menunjukkan kemampuan ekuitas perusahaan dalam menutupi atau memenuhi kewajibannya yaitu hutang jangka panjang, sehingga DER menunjukkan besarnya perbandingan antara hutang jangka panjang dengan ekuitas pemegang saham perusahaan. Ketika perusahaan mampu memenuhi kewajibannya, maka kinerja keuangan perusahaan dinilai baik dan akan menarik minat investor, karena dianggap tidak berisiko untuk menanggung hutang yang dimiliki perusahaan, sehingga harga saham juga meningkat seiring dengan meningkatnya permintaan saham dari investor.

Hal tersebut sejalan dengan teori sinyal yang dikemukakan oleh Brigham (2012) bahwa ketika minat investor naik, maka permintaan juga akan bertambah, sehingga harga saham 
perusahaan di pasar modal juga akan meningkat.

3. Pengaruh Positif Rasio Profitabilitas Terhadap Harga Saham

Hasil pengujian hipotesis secara parsial (Uji $\mathrm{T})$ terhadap rasio profitabilitas yang diukur dengan return on assets (ROA) menunjukkan nilai koefisien sebesar $-0,048983$ dan nilai probabilitas sebesar 0,9920, yang artinya return on asset berpengaruh negatif dan tidak signifikan, sehingga hipotesis ketiga yang mengatakan return on assets berpengaruh positif terhadap harga saham perusahaan sub sektor properti dan real estate ditolak. Hasil tersebut mendukung penelitian terdahulu yang dilakukan oleh Valintino (2013) dan Adipalguna (2016) yang menunjukkan hasil bahwa return on assets (ROA) berpengaruh negatif terhadap harga saham.

Hasil tersebut belawanan dengan pendapat yang dikemukakan oleh Lestari (2007) bahwa semakin tinggi rasio ROA maka semakin baik produktivitas aset dalam memperoleh keuntungan bersih. Ketika nilai rasio meningkat, maka akan meningkatkan daya tarik minat investor karena tingkat return yang diperolah atas investasi juga akan meningkat, sehingga harga saham juga akan ikut meningkat. Akan tetapi, ketika rasio ini menurun atau rendah, minat investor juga akan berkurang, dengan anggapan perusahaan tidak mampu memaksimalkan aset yang dimiliki untuk menghasilkan laba, sehingga harga saham di pasar modal juga akan ikut menurun.

Hal tersebut sejalan dengan teori sinyal yang dikemukakan oleh Brigham (1997) bahwa informasi dari emiten dapat direspon berbeda oleh investor (positif atau negatif), yang akan mempengaruhi fluktuasi harga saham. Jika informasi tersebut merupakan sinyal positif, maka memicu kenaikan harga saham. Namun apabila informasi tersebut merupakan sinyal negatif, maka memicu penurunan harga saham.

Pihak inverstor harus
memperhatikan unsur yang terdapat dalam aktiva selain aset, yakni modal dan hutang. Walaupun laba yang dihasilkan cukup tinggi, namun laba tersebut juga digunakan untuk memenuhi kewajiban yang dimiliki oleh perusahaan. Nilai ROA yang tinggi tidak menjamin nilai yang tinggi terhadap return yang diperoleh atas investasi karena adanya unsur kewajiban tersebut, sehingga dapat dikatakan bahwa peningkatan ROA tidak berdampak pada peningkatan harga saham perusahaan (Ahmaddin, 2015).

4. Pengaruh Positif Rasio Aktivitas Terhadap Harga Saham

Hasil pengujian hipotesis secara parsial (Uji T) terhadap rasio aktivitas yang diukur dengan total asset turn over (TATO) menunjukkan nilai koefisien sebesar 4928,443 dan nilai probabilitas sebesar 0,1736, yang artinya total asset turn over berpengaruh positif dan tidak signifikan, sehingga hipotesis keempat yang mengatakan total asset turn over berpengaruh positif terhadap harga saham perusahaan sub sektor properti dan real estate ditolak. Hal tersebut sejalan dengan hasil penelitian yang dilakukan oleh Nugraha (2016) dan Junaeni (2017) menunjukkan hasil bahwa variabel TATO berpengaruh negatif terhadap harga saham.

Menurut Munawir (2010) bahwa turn over yang tinggi menunjukkan manajemen yang efektif, tetapi dapat 
juga turn over yang tinggi menunjukkan aset perusahaan yang sudah tua dan sudah habis disusut, jadi turn over yang tinggi ini disebabkan karena keadaan perusahaan. Hal ini mengindikasi bahwa nilai turn over yang tinggi dapat menurunkan harga saham. Perusahaan tidak dapat memaksimalkan perputaran aset yang dimilikinya untuk melakukan penjualan atau memperoleh laba. Selain itu, apabila penjualan mengalami peningkatan, belum tentu laba yang diperoleh juga meningkat, karena laba tersebut sebagian digunakan untuk memenuhi kewajiban yang dimiliki perusahaan.

Hal tersebut didukung oleh teori sinyal yang dikemukakan oleh Brigham (2012) ketika perusahaan dinilai memiliki turn over yang tinggi, maka investor akan menilai hal tersebut sebagai sinyal negatif karena menilai perusahaan tidak dapat memaksimalkan perputaran aset yang dimiliki untuk melakukan penjualan atau memperoleh laba. Dari hal tersebut kemudian menurunkan minat investor untuk berinvestasi, sehingga harga saham perusahaan juga ikut menurun di pasar modal.

\section{KESIMPULAN DAN SARAN}

\section{Kesimpulan}

1. Rasio likuiditas yang diukur dengan rasio Current Ratio (CR) menunjukkan hasil bahwa terdapat pengaruh positif dan tidak signifikan CR terhadap harga saham perusahaan sub sektor properti dan real estate yang terdaftar di Bursa Efek Indonesia tahun 2015-2017. Hipotesis pertama yang mengatakan CR berpengaruh positif terhadap harga saham perusahaan sub sektor properti dan real estate yang terdaftar di Bursa Efek Indonesia tahun 2015-2017 ditolak. Hal ini dibuktikan dengannilai koefisien sebesar 0,221616 dan nilai probabilitas sebesar 0,9040yang lebih besar dari nilai signifikansi 5\% $(0,9040$ $>0,05$ ).

2. Rasio solvabilitas yang diukur dengan rasio Debt to Equity Ratio (DER) menunjukkan hasil bahwa terdapat pengaruh positif dan tidak signifikan DER terhadap harga saham perusahaan sub sektor properti dan real estate yang terdaftar di Bursa Efek Indonesia tahun 2015-2017. Hipotesis kedua yang mengatakan DER berpengaruh negatif terhadap harga saham perusahaan sub sektor properti dan real estate yang terdaftar di Bursa Efek Indonesia tahun 2015-2017 ditolak. Hal ini dibuktikan dengan nilai koefisien sebesar 0,145025 dan nilai probabilitas sebesar 0,9679 yang lebih besar dari nilai signifikansi $5 \%(0,9679>0,05)$.

3. Rasio profitabilitas yang diukur dengan rasio Return On Asset (ROA) menunjukkan hasil bahwa terdapat pengaruh negatif dan tidak signifikan ROA terhadap harga saham perusahaan sub sektor properti dan real estate yang terdaftar di Bursa Efek Indonesia tahun 2015-2017. Hipotesis ketiga yang mengatakan ROA berpengaruh positif terhadap harga saham perusahaan sub sektor properti dan real estate yang terdaftar di Bursa Efek Indonesia tahun 2015-2017 ditolak. Hal ini dibuktikan dengan nilai koefisien sebesar 0,048983 dan nilai probabilitas sebesar 0,9920 yang lebih besar dari nilai signifikansi 5\% $(0,9920>0,05)$.

4. Rasio aktivitas yang diukur dengan rasio Total Asset Turn Over (TATO) menunjukkan hasil bahwa terdapat pengaruh positif dan tidak signifikan TATO terhadap harga saham perusahaan sub sektor properti dan real estate yang terdaftar di Bursa Efek 
Indonesia tahun 2015-2017. Hipotesis keempat yang mengatakan TATO berpengaruh positif terhadap harga saham perusahaan sub sektor properti dan real estate yang terdaftar di Bursa Efek Indonesia tahun 2015-2017 ditolak. Hal ini dibuktikan dengan nilai koefisien sebesar 4928,443dan nilai probabilitas sebesar 0,1736 yang lebih besar dari nilai signifikansi 5\% $(0,1736$ $>0,05)$.

\section{Saran}

1. Pihak manajemen perusahaan harus mampu mengelola aset dan dana yang berasal dari investor agar mampu meningkatkan harga saham perusahaan.

2. Calon investor yang akan berinvestasi dapat menggunakan variabel Current Ratio (CR), Debt to Equity Ratio (DER), Return On Asset (ROA), dan Total Asset Turn Over (TATO) sebagai bahan pertimbangan untuk menilai perusahaan, karena dari variabel tersebut dapat digunakan untuk melihat efektifitas manajemen perusahaan dan menilai kinerja keuangan perusahaan.

3. Bagi peneliti yang akan meneliti dengan topik sejenis sebaiknya menggunakan variabel independen selain Current Ratio (CR), Debt to Equity Ratio (DER), Return On Asset (ROA), dan Total Asset Turn Over (TATO) seperti Return On Equity, Debt to Asset Ratio, Cash Ratio, Net Profit Margin, Earning Per Sheet, Price Book Value yang dapat digunakan untuk menguji pengaruh terhadapharga saham, memperluas sampel perusahaan dan memperpanjang periode penelitian agar diperoleh hasil yang lebih baik. Selain menggunakan variabel independen yang lain, alangkah baiknya untuk penelitian berikutnya mengambil obyek penelitian pada sub sektor selain properti dan real estate, seperti perbankan, pertambangan, manufaktur, dll.

\section{DAFTAR PUSTAKA}

Adipalguna, I G N Sudangga dan Anak Agung Gede Suarjaya. (2016) Pengaruh Likuiditas, Solvabilitas, Aktivitas, Profitabilitas, Dan Penilaian Pasar Terhadap Harga Saham Perusahaan LQ45 Di BEI. EJurnal Manajemen Unud, Vol.5 No.12. Universitas Udayana Bali.

Ahmaddin, Aditya Ferri. (2015). Analisis Fundamental Dan Risiko Sistematik Terhadap Harga Saham Perbankan Yang Terdaftar Pada Indeks LQ 45: Studi Pada Bursa Efek Indonesia Periode Juni 2011 - Juni 2014. Undergraduate Thesis. Universitas Islam Negeri Maulana Malik Ibrahim.

Brigham, Eugene F dan Gapenski, Louis C. (1997). Financial Management Theory and Practice. Orlando: The Dryden Press.

Brigham, Eugene F dan Houston, J,F. (2012). Dasar-Dasar Manajemen Keuangan. Edisi Kesepuluh. Jakarta: Erlangga.

Bringham, Eugene $\mathrm{F}$ dan Houston, J.F. (2013). Dasar-Dasar Manajemen Keuangan. Edisi Kesebelas Buku Kedua. Jakarta: Salemba Empat.

Darmadji, Tjiptono dan Fakhrudin Hendi. (2012). Pasar Modal di Indonesia. Edisi Ketiga. Jakarta: Salemba Empat.

Fahmi, Irham. (2012). Analisis Laporan Keuangan. Cetakan Kedua. Bandung: Alfabeta.

Fahmi, Irham. (2014). Analisis Laporan Keuangan. Bandung: Alfabeta. 
Ghozali, Imam. (2011). Aplikasi Analisis Multivariate denga Program IBM SPSS 19. Edisi Kelima. Semarang: Universitas Diponegoro.

Harahap, Sofyan Syafri. (2009). Teori Kritis Laporan Keuangan. Jakarta: Bumi Aksara.

Harahap, Sofyan Syafri. (2010). Analisis Kritis Atas Laporan Keuangan. Jakarta: Rajawali Persada.

Harahap, Sofyan Syafri. (2013). Analisis Kritis Atas Laporan Keuangan. Jakarta: PT Raja Grafindo Persada.

Harjito, A dan Martono. (2014). Manajemen Keuangan. Edisi ke-2 Cetakan Keempat. Yogyakarta: Ekonisia.

Jama'an. (2008). Pengaruh Mekanisme Corporate Governance dan Kualitas Kantor Akuntan Publik Terhadap Integritas Informasi Laporan Keuangan (Studi Pada Perusahaan Publik Di BEJ). Tesis Strata-2 Program Studi Magister Sains Akuntansi. Universitas Diponegoro Semarang.

Junaeni, Irawati. (2017). Pengaruh EVA, ROA, DER, Dan TATO Terhadap Harga Saham Pada Perusahaan Makanan Dan Minuman Di BEI. Riset Dan Jurnal Akuntansi, Vol 2, No 1. Politeknik Ganesha Medan.

Kasmir. (2010). Analisis Laporan Keuangan. Jakarta: Raja Grafindo Persada.

Kasmir. (2012). Analisis Laporan Keuangan. Jakarta: Raja Grafindo Persada.

Kasmir. (2015). Analisis Laporan Keuangan. Edisi Pertama Cetakan
Kedelapan. Jakarta: Rajawali Persada.

Kusuma, Desta Rizky dan Deny Ismanto. (2012). Modul PraktiumEviews. Yogyakarta: Manajemen Universitas Ahmad Dahlan.

Lestari, Maharani Ika dan Toto Sugiharto. (2007). Bank dan Lembaga Keuangan Lainnya. Jakarta: Raja Grafindo Persada.

Maria. (2014). Pengaruh Total Asset Turn Over (TATO) dan Return On Asset (ROA) Terhadap Harga Saham Pada Perusahaan Pertambangan Yang Terdaftar Di Bursa Efek Indonesia (BEI) Tahun 2010-2012. Jurnal Akuntansi Politeknik Sekayu (ACSY), Vol 1, No 1. Politeknik Negeri Sriwijaya.

Manoppo, Vera Ch. O., dkk (2017). Pengaruh Current Ratio, DER, ROA Dan NPM Terhadap Harga Saham Pada Perusahaan Food And Baverages Yang Terdaftar Di BEI Periode 2013-2015. Jurnal EMBA, Vol 5, No 2. Universitas Sam Ratulangi Manado.

Martalena dan Maya Malinda. (2011). Pengantar Pasar Modal. Bandung: Andi.

Munawir, S. (2001). Analisis Laporan Keuangan. Yogyakarta: Liberty.

Munawir, S. (2005). Analisis Laporan Keuangan. Yogyakarta: Liberty.

Munawir, S. (2010). Analisis Laporan Keuangan. Edisi Keempat Cetakan Kelima Belas. Yogyakarta: Liberty.

Nainggolan, S. G. V. (2008). Pengaruh Variabel Fundamental terhadap Harga Saham Perusahaan Manufaktur di Bursa Efek Indonesia. 
Tesis. Sekolah Pasca Sarjana Universitas Sumatera Utara Medan.

Novitasari, Puput. (2015). Pengaruh Current Ratio, Total Asset Turn Over, Debt to Equity Ratio Dan Return On Equity Terhadap Harga Saham Pada Perusahaan Yang Terdaftar Di JII Periode 2009-2013. JESTT, Vol 2, No 4. Universitas Airlangga.

Nugraha, Rheza Dewangga dan Budi Sudaryanto. (2016). Analisis Pengaruh DPR, DER, ROE, Dan TATO Terhadap Harga Saham (Studi Kasus Pada Perusahaan Industri Dasar dan Kimia Yang Terdaftar di BEI Periode 20102014). Diponegoro Journal Of Management, Vol 5, No 4. Universitas Diponegoro Semarang.

Puspitasari, Meilia Arum. (2018). Analisis Pengaruh Rasio CR, ROA dan DER Terhadap Harga Saham (Studi Kasus Pada Perbankan Umum Go Public Yang Terdaftar di BEI Periode 20132015). Universitas Muhammadiyah Surakarta.

Sandjaja, Ridwan S. dan Inge Barlian. (2003). Manajemen Keuangan Dua. Edisi Keempat. Jakarta: Literata Lintas Media.

Sartono, Agus. (2001). Manajemen Keuangan. Yogyakarta : BPFE.

Sartono, Agus. (2008). Manajemen Keuangan Teori dan Aplikasi Edisi Empat. Yogyakarta: BPFE.

Sawir, A. (2009). Analisis Kinerja Keuangan dan Perencanaan Keuangan Perusahaan. Jakarta: PT Gramedia Pustaka Utama.

Siamat, Dahlan. (2005). Manajemen Lembaga KeuanganKebijakan
Moneter dan Perbankan. Edisi Kelima. Jakarta: FE UI.

Setiyawan, Indra dan Pardiman. (2014). Pengaruh Current Ratio, Inventory Turnover, Time Interest Earned Dan Return On Equity Terhadap Harga Saham Pada Perusahaan Manufaktur Sektor Barang Konsumsi Yang Terdaftar Di Bei Periode 2009-2012. Yogyakarta: Universitas NegeriYogyakarta.

Spence, Michael. (1973). Job Market Signaling. The Quarterly Journal of Economics, Vol 87, No.3. The MIT Press.

Suharyadi dan Purwanto S.K. (2009). Statistika Untuk Ekonomi dan Keuangan Modern. Edisi Kedua. Jakarta: Salemba Empat.

Supomo, Bambang dan Nur Indriantoro. (2002). Metodologi Penelitian Bisnis. Cetakan Kedua. Yogyakara: Penerbit BFEE UGM.

Suryawan, I Dewa Gede, dan I Gede AryWirajaya. (2017). Pengaruh Current Ratio, Debt to Equity Ratio Dan Return On Assets Pada Harga Saham. E-Jurnal Akuntansi Universitas Udayana, Vol 21, No 2. Universitas Udayana Bali.

Sutrisno. (2012). Manajemen Keuangan Teori, Konsep dan Aplikasi. Yogyakarta: EKONISIA.

Syamsuddin, Lukman. (2007). Manajemen Keuangan Perusahaan : Konsep Aplikasi dalam Perencanaan, Pengawasan, dan Pengambilan Keputusan. Jakarta: Raja Grafindo Persada.

Tandelilin, Eduardus. (2010). Portofolio dan Investasi: Teori dan Aplikasi. 
Edisi Pertama. Yogyakarta:

Kanisius.

Undang-Undang No.8 Tahun 1995

Tentang Pasar Modal.

Valintino, reynard \& Lana Sularto. (2013).

Pengaruh return on asset (ROA), current ratio $(C R)$, return on equity (ROE) debt to equity ratio (DER), dan earning per share (EPS) terhadap harga saham perusahaan manufaktur sektor industri barang konsumsi di BEI. Bandung: Proceeding PESAT (Psikologi, Ekonomi, Sastra, Arsitektur dan Teknik Sipil), Vol. 5.

Zuliarni, Sri. (2012). Pengaruh Kinerja Keuagan Terhadap Harga Saham pada Perusahaan Mining and Mining Service di Bursa Efek Indonesia. Jurnal Aplikasi Bisnis, Vol 3, No 1. Universitas Riau. 